\title{
Remote sensing analysis reveals habitat, dispersal corridors and expanded distribution for the Critically Endangered Cross River gorilla Gorilla gorilla diehli
}

\author{
Richard A. Bergl, Ymke Warren, Aaron Nicholas, Andrew Dunn \\ In A OY OM IMONG, JACQUELINE L. SUNDERLAND-GRoves and John F. OATES
}

\begin{abstract}
Habitat loss and fragmentation are among the major threats to wildlife populations in tropical forests. Loss of habitat reduces the carrying capacity of the landscape and fragmentation disrupts biological processes and exposes wildlife populations to the effects of small population size, such as reduction of genetic diversity and increased impact of demographic stochasticity. The Critically Endangered Cross River gorilla Gorilla gorilla diehli is threatened in particular by habitat disturbance because its population is small and it lives in an area where high human population density results in intense exploitation of natural resources. We used remotely-sensed data to assess the extent and distribution of gorilla habitat in the Cross River region and delineated potential dispersal corridors. Our analysis revealed $>8,000 \mathrm{~km}^{2}$ of tropical forest in the study region, $2,500 \mathrm{~km}^{2}$ of which is in or adjacent to areas occupied by gorillas. We surveyed 12 areas of forest identified as potential gorilla habitat, 10 of which yielded new records of gorillas. The new records expand the known range of the Cross River gorilla by $>50 \%$, and support genetic analyses that suggest greater connectivity of the population than previously assumed. These findings demonstrate that considerable connected forest habitat remains and that the area could potentially support a much larger gorilla population if anthropogenic pressures such as hunting could be reduced.
\end{abstract}

Keywords Cameroon, Cross River gorilla, forest, fragmentation, Gorilla gorilla diehli, Nigeria, range, remote sensing

Richard A. Bergl (Corresponding author) North Carolina Zoological Park, Asheboro, North Carolina, USA. E-mail richard.bergl@nczoo.org

Ymke Warren, Aaron Nicholas and Jacqueline L. SunderlandGroves ${ }^{\dagger}$ Wildlife Conservation Society, Takamanda-Mone Landscape Project, South West Region, Limbe, Cameroon

Andrew Dunn and Inaoyom Imong Wildlife Conservation SocietyNigeria, Calabar, Nigeria

John F. OAtes Department of Anthropology, Hunter College CUNY, New York, USA

${ }^{\dagger}$ Current address: Center for International Forestry Research, Bogor, Indonesia

Received 27 August 2010. Revision requested 14 December 2010.

Accepted 22 December 2010. First published online 1 November 2011.

\section{Introduction}

T oss of forest and hunting throughout much of the 1 tropics is resulting in increasing levels of threat for many wildlife populations. Primates are particularly vulnerable given the reliance of most species on tropical forest habitats, their large body size and slow reproductive rate. Forty-eight percent of primate species are threatened, and all great ape taxa are either Endangered or Critically Endangered (IUCN, 2010). Deforestation, bushmeat hunting, or a combination of the two, have pushed several primate taxa to the verge of extinction (e.g. the silky sifaka Propithecus candidus, Delacour's langur Trachypithecus delacouri, the roloway monkey Cercopithecus diana roloway, the eastern black crested gibbon Nomascus nasutus, the Sumatran orang-utan Pongo abelii; Mittermeier et al., 2010) and some may have recently gone extinct (e.g. Miss Waldron's red colobus Procolobus badius waldroni; Oates et al., 2000; McGraw, 2005).

Loss and modification of primate habitat from logging, shifting agriculture, harvesting of fuelwood, creation of grazing land and clearance for plantation farming have long been recognized as serious threats to African primate populations (Cowlishaw \& Dunbar, 2000; Wilkie \& Laporte, 2001; Plumptre et al., 2003). Such activities destroy, degrade and subdivide the habitat that forest primates depend upon. Although some primates have been shown to occur at higher densities in disturbed habitats (Johns \& Skorupa, 1987; Plumptre \& Reynolds, 1994), unless the intensity of logging or agricultural activities is extremely low (Ancrenaz et al., 2010) such disturbance is likely to have a significantly negative impact on abundance of primates (Chapman et al., 2006).

High intensity forest loss and disturbance is common throughout African primate habitats and has been occurring for decades. High rates of human population growth in combination with the close relationship between human population density and rates of deforestation (Barnes, 1990; Harcourt, 1996; Cowlishaw \& Dunbar, 2000) have resulted in substantial losses of African tropical forests. In 1992 it was estimated that Central Africa had lost $>40 \%$ of its original closed-canopy tropical moist forest area and West Africa $>88 \%$ (Naughton-Treves \& Weber, 2001). Between 1990 and 2010, $>60$ million ha of forest are estimated 
to have been lost in Africa and several countries (e.g. Democratic Republic of Congo) are estimated to lose 250,000-500,000 ha of forest annually (FAO, 2010). The forest that remains is becoming increasingly fragmented, reducing available habitat area and subdividing primate populations. More than $65 \%$ of forest fragments in Africa where primates are found have an area of $<_{1} \mathrm{~km}^{2}$, far too small to support viable populations in the long term (Harcourt \& Doherty, 2005).

The Cross River gorilla Gorilla gorilla diehli, endemic to the southern Nigeria-Cameroon border region, is categorized as Critically Endangered on the IUCN Red List (Oates et al., 2008). There are probably $<300$ individuals of this subspecies, living in c. 11 hill areas across a landscape with varying degrees of fragmentation (Oates et al., 2007). This fragmentation is exacerbated by hunting, which also appears to limit movement of gorillas between localities, a phenomenon observed in other large mammal taxa (Pattanavibool \& Dearden, 2002). Although these gorillas are now concentrated in hill areas, in the early 2oth century the subspecies occurred in at least some of the lowland areas between the current known localities (Mansfield, 1908) and there have been occasional reports of gorillas in lowland areas in recent years (Fay, 1987; Bucknell \& Groves, 2002; Imong \& Dunn, 2005). Efforts to conserve Cross River gorillas have been hampered by a limited knowledge of the distribution of forest throughout the subspecies' range, the extent of habitat fragmentation, and of the patterns of movement of the gorillas across the landscape.

We used remotely-sensed data to analyse land cover throughout the range of the Cross River gorilla. We created a map of land cover for the Cross River region, analysed the distribution of habitat types relative to known gorilla localities and identified potential habitat linkages and corridors between localities of the Cross River gorilla. The land-cover analysis, in combination with other geographical data, was used to create a model of suitable gorilla habitat. Subsequent field surveys in these areas identified a number of new locality records for the Cross River gorilla, expanding our knowledge of their known range. These new data confirm that the gorillas use many putative habitat corridors and suggest that the size of the population may be larger than current estimates and that the landscape could potentially support a larger gorilla population than previously thought.

\section{Study site}

The study region (Fig. 1) is the north-westernmost part of the Biafran Forests and Highlands, an area recognized for high levels of species richness and endemism in many taxa (Schiøtz, 1999; Brooks et al., 2001; Sunderland et al., 2003; Oates et al., 2004; Bergl et al., 2007). It includes a large block of semi-continuous forest spanning the NigeriaCameroon border. In Nigeria the region is bounded to the west by farmland bordering the forest $\left(8^{\circ} 45^{\prime} \mathrm{E}\right)$ and to the north by the grasslands associated with the Sankwala mountains and Obudu plateau $\left(6^{\circ} 30^{\prime} \mathrm{N}, 1,600 \mathrm{~m}\right.$ altitude). The eastern border of the study area is the central Bamenda Highlands $\left(10^{\circ} \mathrm{E}\right.$, up to $2,000 \mathrm{~m}$ ), and the southern margin is formed by the Cross River $\left(5^{\circ} 40^{\prime} \mathrm{N}, 100 \mathrm{~m}\right)$.

A combination of wide altitudinal range, high but seasonal rainfall and human activity creates a varied habitat with a range of forest types in this region. The lowland areas (i.e. below c. $500 \mathrm{~m}$ ) consist of semi-deciduous Guineo-Congolian high forest with a high canopy and limited understorey vegetation (Sunderland et al., 2003). At $500-1,000 \mathrm{~m}$ the vegetation shifts from lowland forest to mid elevation or submontane forest. This forest is typified by a lower canopy, denser understorey vegetation, more epiphytes and lower tree diversity (Oates et al., 2003). A transition to montane forest begins at c. 1,000 m. Here the canopy is even lower than in the submontane areas and is often discontinuous; epiphytes are common and the density of herbaceous vegetation high (Oates et al., 2003; Imong, 2005). At higher elevations, such as on the northern edge of the study region, montane forest is often limited to the bottoms of valleys with their associated streams and higher levels of moisture. The area between these gallery forests typically comprises high altitude anthropogenic grasslands.

\section{Methods}

\section{Land-cover classification}

We used Landsat 7 imagery (Worldwide Reference System path 187, row 056, 1 January 2003), acquired from GLCF (2010), to create a land-cover classification of the Cross River gorilla's habitat. Spectral data from bands $2-5$ and 7 of the Landsat image were used for the analysis (Boyd \& Duane, 2001; Slayback, 2003). Land-cover classification was conducted using a supervised classification approach with maximum likelihood decision rules implemented in IMAGINE v. 8.6 (Leica Geosystems, Heerbrugg, Switzerland). The land-cover analysis followed an iterative process, alternately classifying the image and making adjustments to the training signatures until a final land-cover classification was produced. We recognized seven land-cover categories: lowland forest, ridge forest, submontane/montane forest, grassland/low vegetation, farmland/disturbed forest, human settlement/bare earth and water, following land-cover classes defined by Sunderland et al. (2003). The classification was smoothed using a sieve filter with which isolated clusters of pixels $(<5)$ were reclassified to the value of the majority of surrounding pixels. The Bechati-Lebialem highlands (south-east of the majority of the gorillas' range) were excluded, as gorillas had not been documented there at the time of our analysis.

The accuracy of the resulting land-cover classification was assessed using a set of 449 ground control points collected 


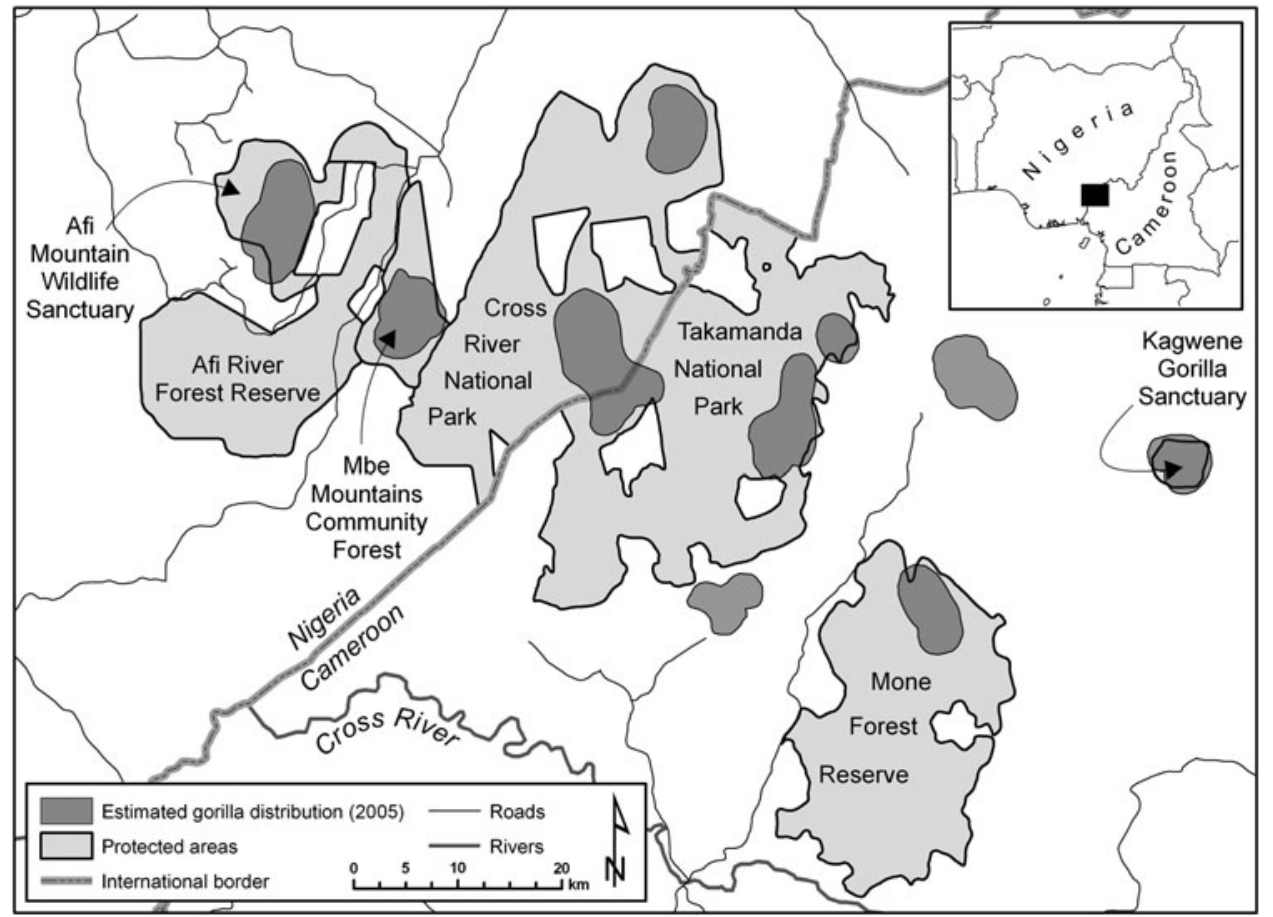

FIG. 1 The range (as of 2005) of the Cross River gorilla Gorilla gorilla diehli on the Nigeria-Cameroon border (the shaded rectangle on the inset shows the location of the main map in West Africa). The gorillas occur in several protected areas of various designations across the landscape. Communal lands also comprise a small but significant portion of the gorillas' range. The Bechati-Lebialem highlands, which also contain a small number of Cross River gorillas, but were not included in the current study, are south-east of the area shown.

with a global positioning system (GPS; Bergl \& Vigilant, 2007; Bergl et al., 2008). All control points were collected within 18 months of the date the Landsat image was acquired, minimizing the chance that land cover had changed significantly between the image capture date and ground-truthing. Control points were not collected in areas of recent forest conversion or at interfaces between two land-cover classes.

\section{Spatial analysis}

Subsequent analysis was conducted with ArcView v. 3.3 and ArcGIS v. 9.2 (ESRI, Redlands, USA). Protected area boundaries, village locations and international boundaries were taken from existing geographical information system (GIS) data (Bucknell \& Groves, 2002; Slayback, 2003; Oates et al., 2004) and manually collected GPS points. Roads and rivers were manually digitized from the 2003 Landsat image and 1:200,000 scale paper maps of the area. Topographical data were taken from the Shuttle Radar Topography Mission Digital Elevation Model (SRTM DEM; USGS, 2004). The approximate range of the Cross River gorilla was determined using all available contemporary confirmed reports of gorillas or gorilla signs (as of June 2005) from published accounts and unpublished reports (Oates et al., 2003, 2004; Sunderland-Groves et al., 2003; Imong \& Dunn, 2005) and GPS points collected in the field by RAB, JSG and other investigators (K. McFarland, pers. comm.; C. Ransom, pers. comm.). We estimated the current range of the gorillas by applying a $1.5-\mathrm{km}$ buffer to these known points, then manually edited the resultant polygons to exclude areas where gorillas are known to be absent (e.g. villages) and to include contiguous forested hill areas.

We took two complementary approaches to identifying potential corridors and habitat linkages between Cross River gorilla localities (i.e. landscape features that, in addition to providing connectivity between two patches of habitat, could potentially support a resident population; Bolger et al., 2001). Firstly, visual inspection of the land-cover classification, satellite imagery and knowledge of the area was used to draw polygons around areas that appeared to provide conduits for the migration of gorillas. This approach allows the identification of large areas and can accommodate potential inaccuracies in the land-cover classification. Secondly, we created a habitat suitability model to determine the optimal pathways between gorilla localities. This more objective and quantitative approach is often better at revealing important areas of connectivity (Gustafson \& Gardner, 1996; Wikramanayake et al., 2004) but can also be affected by small errors in the land-cover classification.

Cross River gorillas concentrate almost all their activities in forested, steep, hilly areas, where hunting pressure is lower, and only occasionally use grasslands, farmland, 
human settlement and other areas, where hunting is intense (Oates et al., 2007). We therefore used four variables to estimate habitat suitability for gorillas across the landscape: land cover, elevation, slope and distance from farmland. Distance from farmland was used as a proxy measure for the degree of human disturbance, as precise data on hunting and other activities are not available. Elevation and slope were derived from the SRTM DEM data set. These variables were selected based on the assumption that gorillas will preferentially use forested, steep, hilly areas that are as far as possible from human influence (Kühl et al., 2009).

To create the habitat suitability model we assigned suitability scores to raster layers in ArcView, on a pixel by pixel basis, for each variable according to the gorillas' known habitat preferences (Table 1). To control for disproportionately low habitat suitability where levels of human activity are high, we assigned habitat suitability scores in a non-linear fashion in areas where land cover was heavily modified by humans (Larkin et al., 2004; Wikramanayake et al., 2004). Although somewhat subjective in nature, such an approach allows for more biologically realistic costing of grid cells than simple equal-interval ranked values (Schadt et al., 2002; Larkin et al., 2004). The raster layers containing the scores for each of the four variables were combined into a single layer representing the habitat suitability model for the entire study area. To determine the areas that represented potential gorilla habitat we calculated the range of composite habitat suitability values that captured the known distribution of the gorillas. We then selected all pixels in the cost surface within this range to identify other areas of potential gorilla habitat.

We used least-cost path analysis to quantify the ease with which gorillas could disperse across the landscape based on the habitat suitability model. Least-cost path analysis allows the selection of the path between two points or that represents the least costly route between the two areas according to a number of variables (Larkin et al., 2004; Rouget et al., 2006). Least-cost paths are calculated using a cost raster, where each pixel of the raster has a value assigned according to the level of impedance represented by that pixel. The least-cost analysis determines the shortest path across the cost raster that accumulates the minimal possible cost. We used the habitat suitability model as a cost raster to calculate least-cost paths between all adjacent gorilla localities that were connected by habitat corridors or linkages; 500-m buffers were then applied to the least-cost paths to identify core corridor areas.

\section{Field surveys}

Following the initial analyses several areas that the habitat model identified as having the characteristics of gorilla habitat were targeted for field surveys. Most of these areas had no previous records of gorillas, although some areas where gorillas had previously been documented were resurveyed in the course of fieldwork. All fieldwork was conducted between January 2004 and December 2008.

In Cameroon a total of seven forest areas were selected based on the habitat suitability model, interviews with local hunters and logistical constraints. In five areas to the north and east of Mone Forest Reserve local hunters were used to guide field teams to areas identified as gorilla habitat, focusing on steep slopes and away from areas of human activity. Data were collected using travel reconnaissance walks where observations of all great ape sign visible from the path walked were recorded (Kühl et al., 2008). Additionally, two highland areas within Mone Forest Reserve were surveyed using guided reconnaissance walks (Kühl et al., 2008). Survey lines for these surveys were created using Distance v. 5.o (Thomas et al., 2006). During these guided reconnaissance surveys lowland forest adjacent to the highland areas was also searched for gorillas.

In Nigeria five areas of potential gorilla habitat were identified. Three areas in the northern portion of the Okwangwo Division of Cross River National Park were surveyed, as were two forest areas to the north of the Afi Mountain Wildlife Sanctuary. Both guided searches (assisted by local hunters) and sweep surveys (McNeilage et al., 2001) utilizing four to five field teams were used to search for evidence of gorillas. For the sweep surveys the survey area

TABLE 1 Pixel-specific habitat suitability scores (see text for details; lower numbers indicate higher suitability) for the Cross River gorilla Gorilla gorilla diehli, assigned based on land cover, altitude, slope and distance from farmland.

\begin{tabular}{|c|c|c|c|c|c|c|c|}
\hline Land cover & Suitability & Altitude (m) & Suitability & $\begin{array}{l}\text { Slope } \\
\text { (degrees) }\end{array}$ & Suitability & $\begin{array}{l}\text { Distance from } \\
\text { farmland }(\mathrm{m})\end{array}$ & Suitability \\
\hline $\begin{array}{l}\text { Montane \& submontane } \\
\text { forest }\end{array}$ & 1 & $1,000+$ & 1 & $40+$ & 1 & $4,000+$ & 1 \\
\hline Ridge forest & 2 & $750-1,000$ & 2 & $30-40$ & 2 & $3,000-4,000$ & 2 \\
\hline Lowland forest & 3 & $500-750$ & 3 & $20-30$ & 3 & $2,000-3,000$ & 3 \\
\hline Grassland & 10 & $250-500$ & 4 & $10-20$ & 4 & $1,000-2,000$ & 4 \\
\hline \multirow[t]{3}{*}{ Farmland } & 50 & $0-250$ & 5 & $0-10$ & 5 & $500-1,000$ & 5 \\
\hline & & & & & & $250-500$ & 25 \\
\hline & & & & & & $0-250$ & 50 \\
\hline
\end{tabular}


was divided into equally-sized sectors using $\operatorname{ArcGIS}$ and each team was assigned a specific sector to search. Each team searched their assigned sectors simultaneously using travel reconnaissance walks (Kühl et al., 2008).

In all cases the presence of lobed dung and/or ground nests was used to differentiate gorilla nest sites from chimpanzee nest sites. Both gorilla day and night nests were included as evidence of gorilla presence, but only when lobed dung was associated with the nests. The locations of nest sites and other gorilla evidence were recorded with a GPS. New evidence was combined with existing data to estimate a revised range for the gorillas by applying a $1.5-\mathrm{km}$ buffer to recorded points and connecting occupied, adjacent highlands joined by unbroken forest.

\section{Results}

\section{Accuracy assessment}

Overall, the land-cover classification was highly accurate, with each of the land-cover classes having $90 \%$ or higher accuracy. Misclassification tended to involve either the farmland and disturbed forest class, or the grassland and low vegetation class. Farmland and disturbed forest was erroneously classified as one of the forest types an average of $4 \%$ of the time, and thus the classification probably slightly underestimates the extent of agricultural activity.

\section{Land-cover patterns}

Significant areas of forest are present throughout the range of the Cross River gorilla (Fig. 2a). Almost 8,000 km² (61\%) of the classified area is forest (lowland, ridge, submontane and montane) and c. 2,000 $\mathrm{km}^{2}$ of this lies within protected areas or forest reserves, including settled enclaves, and an additional $500 \mathrm{~km}^{2}$ lies in known gorilla areas outside any protected area. The most substantial areas of continuous forest are in the centre of the gorillas' range, primarily within Cross River National Park (Okwangwo Division) and Takamanda National Park. Large areas of forest also exist in Mone Forest Reserve. Of particular note are the large tracts of submontane and montane forest in the Upper Mbulu area, north of Mone Forest Reserve; these represent the largest expanses of highland forest in the study area but are without any protected status. Only $5 \%$ of the area within protected areas and forest reserves is nonforest and this is concentrated in the village enclaves of the Cross River and Takamanda National Parks. However, within $5 \mathrm{~km}$ of the protected area and forest reserve boundaries is almost $300 \mathrm{~km}^{2}$ of farmland or disturbed forest. Farmland and disturbed forest occurs at the greatest densities surrounding the protected areas in Nigeria and between the Takamanda National Park and Mone Forest Reserve in Cameroon.

\section{Habitat fragmentation and linkages}

Fragmentation of the gorillas' habitat is not as pronounced as their apparently disjunct distribution suggests. No gorilla locality exists in a forest patch that is completely isolated from other such patches by non-forest. There are potential movement corridors or habitat linkages between all localities. In the centre of the gorillas' range there are large habitat linkages between most of the gorilla localities. Extensive highland forest also appears to provide good habitat connectivity between the easternmost localities. Other connections between localities form narrower, more linear corridors, but together the corridors and habitat linkages serve to provide potential conduits for dispersal between the majority of the known gorilla areas.

However, connectivity between gorilla localities is not secure. Afi Mountain in Nigeria is the most westerly and most tenuously connected gorilla locality, with a road and considerable farmland located between it and the nearest gorilla population in the Mbe Mountains to the east. A similar situation exists between Takamanda National Park and Mone Forest Reserve, which are in danger of being isolated from each other by a road and farmland associated with villages. Within the Okwangwo Division of Cross River National Park, expansion of farmland around enclaved villages is constricting forest corridors between the north of the park and central and northern Takamanda.

\section{Habitat suitability model and least-cost paths}

The habitat suitability model (Fig. 2b) illustrates how, despite the fact that most of the gorilla areas are connected by continuous habitat, connectivity between these areas is not equal. In particular, incorporating distance from farmland as a proxy for human disturbance shows the potential impact of activities such as hunting on the ease with which gorillas can move through different areas. The fragile linkage of Afi Mountain to the Mbe Mountains is conspicuous, as in the land-cover analysis, and the impact of human disturbance east of Mbe Mountains becomes more pronounced (although riverine forest in this area may have been confused with farmland and disturbed forest). Likewise, movement between Takamanda National Park and Mone Forest Reserve appears more difficult, as does movement into Takamanda from the gorilla locality immediately south of the National Park.

Sixteen least-cost paths were calculated using the habitat suitability model (Table 2). The paths are $3-27.2 \mathrm{~km}$ long, with a mean length of $16.8 \mathrm{~km}$. The highest and lowest cost paths were the longest and shortest, respectively, but path length did not always predict relative cost. In areas where substantial forest cover is present the least-cost paths tended to approximate the straight-line path between localities, whereas more complex paths were taken in areas of habitat 


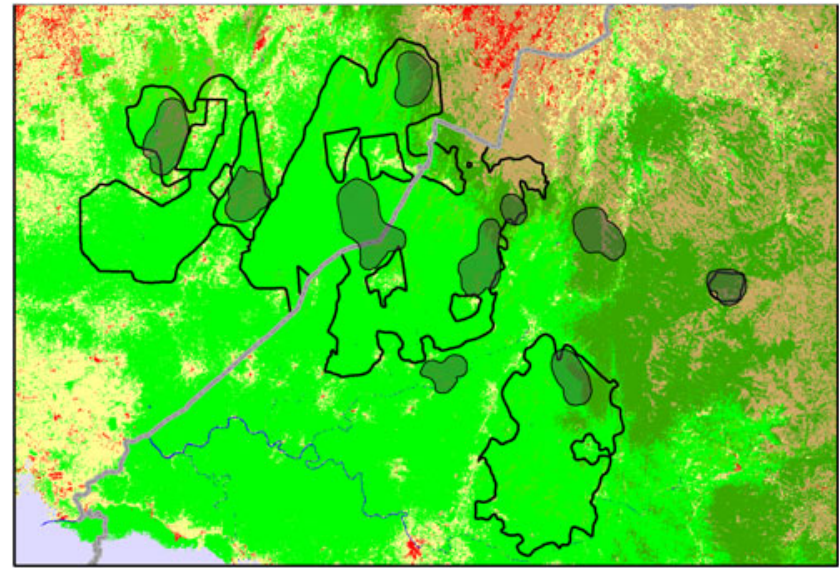

(a)

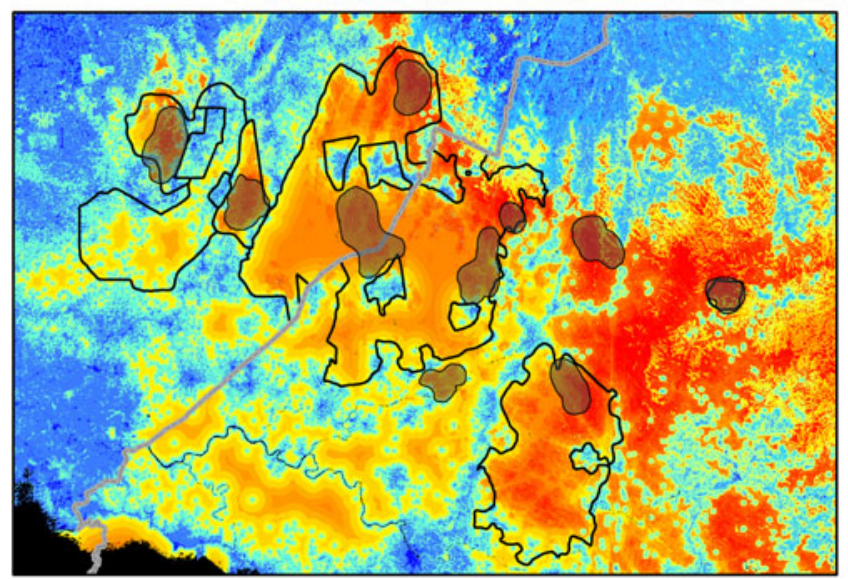

(b)

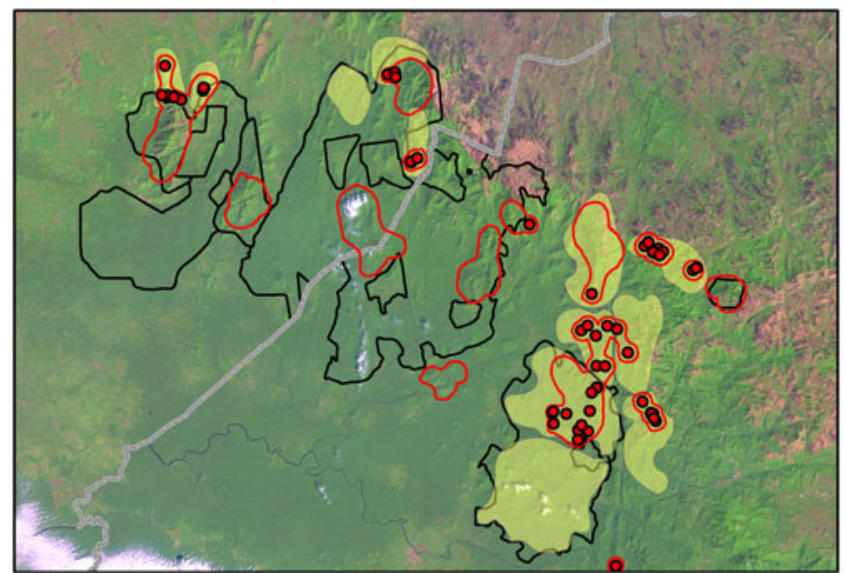

(c)

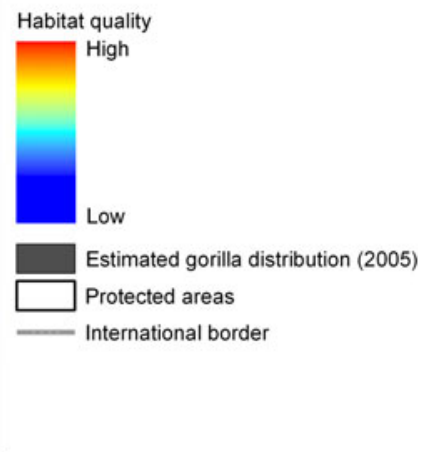

- New gorilla records (this study) Revised gorilla distribution Survey areas International border Protected areas

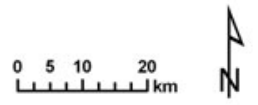

FIg. 2 (a) Land-cover classification of the Cross River gorilla's range (for location names see Fig. 1) based on Landsat data from 2003. (b) Habitat suitability model for the Cross River gorilla (see text for details). (c) Revised distribution of the Cross River gorilla. Survey areas were identified using the range of habitat suitability values that identified known Cross River gorilla range; the surveys produced new evidence of gorillas in areas where they had not previously been recorded and greatly increased the known range of this subspecies.

disturbance. Paths passed almost entirely through one of the three forest classes, with only a small fraction of path composition consisting of grassland $\left(<_{1} \%\right)$. No path crossed through pixels classified as either farmland/disturbed forest or bare earth/human settlement. In some cases (e.g. between Mone Forest Reserve and areas to the north) least-cost analysis selected a path passing adjacent to areas of farmland that would not be likely dispersal routes. These paths were possible because of narrow areas of forest interspersed between the farmland. Overall, because of the apparent underestimation of farmland in the northern portion of the gorillas' range, estimated paths followed more direct routes than are probably realistic.

\section{Field surveys and gorilla range}

We found evidence of gorillas in six of the seven survey areas in Cameroon, substantially extending the range of 
TABLE 2 Length, cost and percentage land-cover composition of the 16 least-cost paths between gorilla localities.

\begin{tabular}{|c|c|c|c|c|c|c|c|c|}
\hline Path between & $\begin{array}{l}\text { Length } \\
(\mathrm{km})\end{array}$ & $\begin{array}{l}\text { Cost } \\
\text { (scaled to } \\
\text { lowest } \\
\text { cost value) }\end{array}$ & $\begin{array}{l}\text { Lowland } \\
\text { forest }(\%)\end{array}$ & $\begin{array}{l}\text { Montane \& } \\
\text { submontane } \\
\text { forest (\%) }\end{array}$ & $\begin{array}{l}\text { Ridge } \\
\text { forest } \\
(\%)\end{array}$ & $\begin{array}{l}\text { Grassland } \\
(\%)\end{array}$ & $\begin{array}{l}\text { Farmland } \\
(\%)\end{array}$ & $\begin{array}{l}\text { Bare earth } \\
\text { \& human } \\
\text { settlement } \\
(\%)\end{array}$ \\
\hline E Takamanda-N Takamanda & 3.0 & 1.0 & 4 & 96 & 0 & 0 & 0 & 0 \\
\hline $\begin{array}{l}\text { Takamanda/Okwangwo-E } \\
\text { Takamanda }\end{array}$ & 11.0 & 5.1 & 93 & 2 & 5 & 0 & 0 & 0 \\
\hline $\begin{array}{l}\text { N Takamanda-Upper } \\
\text { Mbulu }\end{array}$ & 11.5 & 4.3 & 5 & 80 & 14 & 1 & 0 & 0 \\
\hline $\begin{array}{l}\text { S. Takamanda-E } \\
\text { Takamanda }\end{array}$ & 12.5 & 6.7 & 100 & 0 & 0 & 0 & 0 & 0 \\
\hline $\begin{array}{l}\text { Mbe Mt-Takamanda/ } \\
\text { Okwangwo }\end{array}$ & 13.5 & 7.6 & 96 & 0 & 4 & 0 & 0 & 0 \\
\hline Afi Mt-Mbe Mt & 13.5 & 12.4 & 97 & 2 & 1 & 0 & 0 & 0 \\
\hline $\begin{array}{l}\text { Boshi-Takamanda/ } \\
\text { Okwangwo }\end{array}$ & 14.0 & 6.5 & 65 & 1 & 34 & 0 & 0 & 0 \\
\hline E Takamanda-N Mone & 17.5 & 11.2 & 88 & 1 & 11 & 0 & 0 & 0 \\
\hline Upper Mbulu-Kagwene & 17.9 & 4.5 & 0 & 100 & 0 & 0 & 0 & 0 \\
\hline $\begin{array}{l}\text { Takamanda/Okwangwo-N } \\
\text { Takamanda }\end{array}$ & 18.7 & 6.8 & 43 & 26 & 31 & 0 & 0 & 0 \\
\hline S Takamanda-N Mone & 18.8 & 9.7 & 93 & 0 & 7 & 0 & 0 & 0 \\
\hline N Mone-Upper Mbulu & 19.9 & 6.4 & 5 & 94 & 1 & 0 & 0 & 0 \\
\hline $\begin{array}{l}\text { Takamanda/Okwangwo-S } \\
\text { Takamanda }\end{array}$ & 20.4 & 10.1 & 82 & 0 & 18 & 0 & 0 & 0 \\
\hline Boshi-N Takamanda & 23.6 & 6.9 & 0 & 91 & 8 & 0 & 0 & 0 \\
\hline N Mone-Kagwene & 25.2 & 5.8 & 2 & 97 & 1 & 0 & 0 & 0 \\
\hline Mbe Mt-Boshi & 27.2 & 14.5 & 78 & 1 & 21 & 0 & 0 & 0 \\
\hline
\end{tabular}

the Cross River gorilla within, north and east of Mone Forest Reserve (Fig. 2c). The majority of gorilla signs were found in the northern portion of the Reserve, in areas with steep slopes contiguous to the gorillas' known range. In this area groups of 1-8 nests were found. North and east of the Reserve most of the nest sites consisted of single nests, except in the area to the north of Mone where nest groups of six individuals were recorded on two separate occasions. In no cases was gorilla evidence detected in lowland areas, nor was any evidence of gorillas found in the central or southern potions of Mone Forest Reserve. A single nest was recorded in a hilly area south-east of the Reserve boundary.

In Nigeria we confirmed the presence of gorillas in four of the five areas surveyed, extending the range of the gorillas north, beyond the Afi Mountain Wildlife Sanctuary, to the west within the north of Cross River National Park, and into a hill area in central Cross River National Park near the Cameroon border. Nest sites of one, six and 13 nests were found in the areas north of Afi Mountain. Many of these were located in forest close to farm land, and gorilla dung and feeding trails (including damaged banana stems) were observed in six farms visited in the area. Sites with 1-3 nests were found just south of the gorillas' known range in northern Cross River National Park. To the west of this area no nest sites were located but feeding signs, hair and a sighting were recorded. No evidence of gorilla presence was found during surveys of the north-western portion of the Park.

Overall, evidence of gorillas recorded in the field surveys increased the approximate range of the subspecies in the Cross River region by $>50 \%$. The area occupied at known gorilla localities was expanded and several new localities were identified. Many of the new records were in areas previously identified as potential corridor areas.

\section{Discussion}

\section{Status of the Cross River gorilla}

Our analysis of the land cover of the Cross River region highlights both the challenges and opportunities for conservation across this landscape. The use of Landsat imagery facilitated a more precise measurement of the amount of forest cover and how that forest is distributed than was possible using previously available data (e.g. Iremonger et al., 1997; Laporte et al., 1998; Mayeaux et al., 1999; Hansen et al., 2003). There are large areas of intact forest $(>2,500$ $\mathrm{km}^{2}$ in the areas immediately surrounding gorilla localities) in Nigeria and Cameroon. Only a relatively small portion of this area $\left(\right.$ c. $\left.400 \mathrm{~km}^{2}\right)$ is known to be occupied by the Cross River gorilla (Oates et al., 2007). In comparison, Uganda's Bwindi Impenetrable National Park is similar in size and 
supports a comparable number of mountain gorillas Gorilla beringei beringei. However, the amount of forested habitat surrounding the gorillas' known range is considerably greater in the Cross River region than in Bwindi, which is almost entirely surrounded by cultivation. Even if only $50 \%$ of the existing forest represents usable gorilla habitat it is possible that the Cross River area could support a much larger population.

Such estimates of potential gorilla habitat must be viewed with caution, however, as the habitat requirements of mountain and Cross River gorillas are likely to differ considerably. Only limited knowledge of the Cross River gorilla's ecology exists (Oates et al., 2003; McFarland, 2007; Sunderland-Groves et al., 2009) and even these data are from sites that may not be typical of the population as a whole. Similarly, detailed data on forest composition and the availability of gorilla food plants, except for Takamanda National Park (Sunderland et al., 2003), are unavailable for most of the areas under consideration. This lack of understanding of the relationship between the gorillas' ecology and available habitat prevents more precise and sophisticated modelling (Kobler \& Adamic, 2000; Anderson et al., 2003) of how much existing forest represents unoccupied habitat as opposed to unsuitable habitat. Despite this deficit of data, approximate estimates based on forest area are not completely unwarranted. Simple habitat models such as we employed have been demonstrated to be predictive of species' distributions (Alves et al., 2008; Rood \& Ganie, 2010) and anecdotal evidence suggests that, at least for fruiting trees exploited by the gorillas, unoccupied lowland areas contain approximately the same abundance of species as areas occupied by gorillas (T. Sunderland, pers. comm.).

Although we remain circumspect about the number of gorillas this landscape can support, the concordance between apparently good gorilla habitat identified from satellite imagery and evidence of gorillas subsequently discovered in these areas was strong. This finding, in combination with recent genetic data demonstrating that the small size of the Cross River gorilla population is a recent phenomenon (probably the result of hunting as opposed to habitat loss; Bergl et al., 2008; Thalmann et al., 2011), suggests that the region could support a considerably larger gorilla population. Given the greater range documented by our surveys it is important for future research to pursue more accurate estimates of gorilla population size in these new areas and throughout the gorilla's range as a whole.

\section{Corridors}

The land-cover and corridor analyses, in combination with the results of field surveys, support genetic data (Bergl \& Vigilant, 2007) that suggest that movement between gorilla localities does occur. The land-cover analysis also shows that forest in the Cross River region is not as intensely fragmented as habitats for many other threatened species (Schadt et al., 2002; Martinez-Cruz et al., 2004; Miller et al., 2004). All of the known gorilla localities are connected by forest, although sometimes tenuously, to at least one other locality. This relatively high degree of connectivity, in combination with the genetic data, supports the proposition that the majority of Cross River gorillas should be managed as a single population (Oates et al., 2007). Although corridors identified by the land-cover analysis are important for maintaining population connectivity, our surveys suggest that these areas may also support resident gorilla groups, forming several large areas of essentially continuous gorilla habitat. Maintenance of the linkages and corridors between gorilla localities must be a crucial component of any long-term conservation plan for the Cross River gorilla.

While connectivity is present between the gorilla localities, several of the narrower corridors are in danger of being severed and are in need of immediate attention. The Afi Mountain-Mbe Mountains corridor is only $750 \mathrm{~m}$ wide in places and passes through some of the most intensive areas of agriculture in the study region. Likewise, only narrow corridors of forest that pass through large areas of farmland connect Mone Forest Reserve with the Takamanda National Park. If farmland expansion in areas such as these continues, and if human activity in these forests remains high, it is likely that these gorilla localities will become completely isolated from each other.

A further threat to the connectivity of Cross River gorilla localities is the fact that many of the corridors and landscape linkages occur entirely outside any formally protected area. The large highland forest area north of Mone Forest Reserve is, with the exception of the $19 \mathrm{~km}^{2}$ Kagwene Gorilla Sanctuary, without any kind of protected status. These large tracts of submontane and montane forest provide important dispersal routes and habitat for Cross River gorillas. These areas are steadily being eroded by small-scale farming around remote, forest-dependent villages and burning of adjacent grassland by pastoralists. The presence of several large lowland valleys and their associated higher levels of agricultural activity present an additional challenge to gorilla dispersal.

\section{Maintaining gorilla habitat and habitat connectivity}

If habitat connectivity and associated dispersal are to be maintained throughout the range of the Cross River gorilla, immediate action is needed. Although some of the habitat linkages between gorilla localities are relatively secure because of their remoteness and rugged topography, others may be lost in the near future if changes are not made to current patterns of resource exploitation. Enforcement of existing forestry and wildlife laws in and around corridors 
that already have legal protection should be encouraged and made more effective. The central portion of the gorillas' range is within the boundaries of two national parks, and therefore legally protected against both logging and conversion for agriculture. However, law enforcement in these areas has been lax (Oates et al., 2007; Wildlife Conservation Society, unpubl. data); not only has encroachment of farmland into protected areas and reserves such as these been significant but high levels of hunting continue. Recent successes in establishing or upgrading protected areas (e.g. Takamanda National Park) suggest the potential for improved governmental support of conservation activities. However, substantial NGO involvement will be necessary in the immediate future to support protected area management until the capacity of, and support from, government institutions has developed sufficiently.

Protection of corridors outside protected areas also poses significant challenges but is essential to limit fragmentation of the gorilla population. Expansion of existing protected areas or creation of new ones together with a network of protected corridors would be one way to ensure continued connectivity. However, recent successes in protected area creation have resulted in reluctance on the part of some government agencies to gazette additional reserves in this region. One option for preserving currently unprotected lands would be through conservation leases or easements (Main et al., 1999; Czech, 2002; Ferraro \& Simpson, 2002; Pence et al., 2003; Kiss, 2004b). Such approaches could be particularly effective in preserving corridors, as the area needed for protection will be relatively small (and thus cheaper) than an area large enough to support a resident population of gorillas. This leasepurchase concept could be applied both to corridors outside protected areas and enclaves within them. Targeting core corridors, such as those identified in the least-cost path analysis, could further improve both the effectiveness and cost-efficiency of setting aside land for conservation.

An additional and potentially complementary approach to preserving these corridors is through carbon sequestration-based funding mechanisms, and in particular REDD (Reduced Emissions from Deforestation and Forest Degradation). While REDD-based approaches to habitat conservation are relatively new and pose a number of significant challenges (Pollini, 2009; Clements, 2010), they may have the potential to raise significant amounts of money to support conservation initiatives (Ebeling \& Yasué, 2008) and examples of functioning projects are beginning to emerge (Wunder et al., 2008; Bond et al., 2009). Feasibility studies for REDD projects are underway at sites occupied by Cross River gorillas in both Nigeria and Cameroon. Other options being considered are the creation of community forests with low-impact logging rights for local communities and setaside corridor areas. However, care must be taken with all these approaches, and their implementation may be difficult given the potential costs involved and local resistance to the loss of traditional land rights (Noss, 1997; Attwell \& Cotterill, 2000; Ite \& Adams, 2000; Kiss, 2004a). Despite these challenges, there has been some initial success in protecting forest and increasing local support for gorilla conservation through community-based approaches in Mbe Mountains in Nigeria and through the Gorilla Guardian programme in Cameroon (Nicholas, 2009).

\section{Control of hunting}

In addition to preserving habitat corridors, hunting of gorillas (and wildlife in general) must be controlled for dispersal of gorillas between localities to be possible. Hunting appears to contribute to Cross River gorilla population fragmentation as much as habitat loss. Evidence of gorilla presence is rarely observed in lowland areas where human activity levels are high. Thus, if levels of hunting are not reduced the mere presence of habitat corridors will probably not be enough to facilitate movement. As natural resources in lowland areas are depleted by unsustainable hunting and non-timber forest product exploitation, pressure on the more inaccessible highland areas currently occupied by gorillas will increase. Conservation education and enforcement initiatives in both Nigeria and Cameroon have been successful in limiting incidents of gorilla hunting (Oates et al., 2007) but hunting of other species continues almost unabated (Mboh \& Warren, 2007). Although hunting and other activities may not target gorillas, human presence in the forest and associated disturbances (gun shots, snares and camps) may be sufficient to limit the gorillas' movement both within and between highland sites. Intensifying human activity is also likely to increase the exposure of the gorillas to novel pathogens, a documented cause of morbidity and mortality in other ape habitats (Köndgen et al., 2008).

\section{Utility of remote sensing for primate conservation}

Although the utility of remotely-sensed data for studies of primate conservation biology has been recognized for $>20$ years (Green, 1986) few primate studies, and in particular of African primates, have attempted to utilize such data to their full potential (but see Russon et al., 2001; van Schaik et al., 2001; Miller et al., 2004). In contrast, research and applied conservation work on other taxa has utilized these data effectively in a variety of contexts (e.g. Alves et al., 2008; Buchanan et al., 2008; McDermid et al., 2009). Our analysis demonstrates that valuable insights into habitat availability, fragmentation and corridors are possible with relatively small investments of time and money. By using remotelysensed data to target field surveys we were able to document more accurately the known range of the Cross River gorilla and corroborate genetic analyses suggesting dispersal through 
several corridor areas. Such insights would be either impossible or prohibitively expensive using methodologies such as landscape-wide field surveys and aerial photography. The information gained via remote sensing analysis has had direct utility for research and conservation efforts, and the combined results of the GIS analysis and fieldwork are currently being used to plan ongoing conservation efforts in both Nigeria and Cameroon.

More extensive analyses of remotely-sensed data are possible, especially if more detailed habitat preference or high-resolution environmental data are available. Such data can allow more accurate predictions and identification of potential habitat, as well as long-term monitoring of changes in land cover at a very fine scale. Additionally, studies currently underway will investigate in greater detail potential ecological differences between known and possible gorilla habitat and the efficacy of putative habitat corridors. The findings of such studies will facilitate more robust assessment of the overall potential for the landscape to support a larger gorilla population and the maintenance of connectivity between core areas for the Cross River gorilla.

\section{Acknowledgements and dedication}

Financial support for this project was provided by the US Fish and Wildlife Service, National Geographic Society Conservation Trust, the Conservation International Primate Action Fund, Margot Marsh Biodiversity Foundation, Lincoln Park Zoo and Primate Conservation Inc.. We thank the National Parks Service (Nigeria), the Cross River State Forestry Commission (Nigeria), the Ministry of Forests and Wildlife (Cameroon) and the Ministry of Scientific and Technical Research (Cameroon) for granting us permission to conduct field work in areas under their management. We also thank M. Ashu, E. Nwufoh, A. Ekinde, H. Mboh, C. Ransom, N. Mkpe, M. Tabeh, P.A. Stott, P. Khumbah, P. Jenkins, L. Gadsby, T. Sunderland and local field assistants too numerous to mention. We are grateful to the many local communities that provided support during the course of our work.

This work is dedicated to the memory of Ymke Warren, who was killed in Cameroon prior to publication of this study.

\section{References}

Alves, M.S., Pimm, S.L., Alline, S., Raposo, M.A., De L. Brooke, M., Harris, G. et al. (2008) Mapping and exploring the distribution of the Vulnerable grey-winged cotinga Tijuca condita. Oryx, 42, 562-566.

Ancrenaz, M., Ambu, L., Sunjoto, I., Ahmad, E., Manokaran, K., Meijaard, E. \& Lackman, I. (2010) Recent surveys in the forests of Ulu Segama Malua, Sabah, Malaysia, show that orangutans (P. p. morio) can be maintained in slightly logged forests. PLoS One, 5(7), e11510.
Anderson, R.P., Lew, D. \& Peterson, A.T. (2003) Evaluating models of species' distributions: criteria for selecting optimal models. Ecological Modelling, 162, 211-232.

Attwell, C.A.M. \& Cotterill, F.P.D. (2000) Postmodernism and African conservation science. Biodiversity and Conservation, 9, 559-577.

B A Rnes, R.F.W. (1990) Deforestation in tropical Africa. African Journal of Ecology, 28, 161-173.

Bergl, R.A., Bradley, B.J., Nsubuga, A.M. \& Vigilant, L. (2008) Genetic effects of habitat fragmentation, population size and demographic history on primate populations: the Cross River gorilla in a comparative context. American Journal of Primatology, 70, 848-859.

Bergl, R.A., Oates, J.F. \& Fotso, R. (2007) Distribution and protected area coverage of endemic taxa in West Africa's Biafran forests and highlands. Biological Conservation, 134, 195-208.

Bergl, R.A. \& Vigilant, L. (2007) Genetic analysis reveals population structure and recent migration within the highly fragmented range of the Cross River gorilla (Gorilla gorilla diehli). Molecular Ecology, 16, 501-516.

Bolger, D.T., Scott, T.A. \& Rotenberry, J.T. (2001) Use of corridor-like landscape structures by bird and small mammal species. Biological Conservation, 102, 213-224.

Bond, I., Grieg-Gran, M., Wertz-Kanounnikoff, S., Hazlewood, P., Wunder, S. \& Angelsen, A. (2009) Incentives to Sustain Forest Ecosystem Services: A Review and Lessons for $R E D D$. International Institute for Environment and Development, London, UK.

Boyd, D.S. \& Duane, W.J. (2001) Exploring spatial and temporal variation in the middle infrared reflectance measured from the tropical forests of West Africa. International Journal of Remote Sensing, 22, 1861-1878.

Brooks, T., Balmford, A., Burgess, N., Fjelds L.A., Moore, J. et al. (2001) Towards a blueprint for conservation in Africa. BioScience, 51, 613-624.

Buchanan, G.M., Butchart, S.H.M., Dutson, G., Pilgrim, J.D., Steininger, M.K., Bishop, K.D. \& Mayaux, P. (2008) Using remote sensing to inform conservation status assessment: estimates of recent deforestation rates on New Britain and the impacts upon endemic birds. Biological Conservation, 141, 56-66.

Bucknell, D. \& Groves, J.L. (2002) Local Perception of the Population Size, Distribution and Ranging Behaviour of the Cross River Gorilla within the Takamanda and Mone Forest Reserves and the Mbulu Forest, Cameroon. Wildlife Conservation Society Report, New York, USA.

Chapman, C.A., Lawes, M. \& Eeley, H.A.C. (2006) What hope for African primate diversity? African Journal of Ecology, 44, 116-133.

Clements, T. (2010) Reduced Expectations: the political and institutional challenges of REDD+. Oryx, 44, 309-310.

Cowlishaw, G. \& Dunbar, R.I.M. (2000) Primate Conservation Biology. University of Chicago Press, Chicago, USA.

Czech, B. (2002) A transdisciplinary approach to conservation land acquisition. Conservation Biology, 16, 1488-1497.

Ebeling, J. \& Yasué, M. (2008) Generating carbon finance through avoided deforestation and its potential to create climatic, conservation and human development benefits. Philosophical Transactions of the Royal Society, B, 363, 1917-1924.

FAO (Food and Agriculture Organization) (2010) Global Forest Resources Assessment 2010. Food and Agriculture Organization of the United Nations, Rome, Italy.

FAy, J.M. (1987) Report on the Participation of J. Michael Fay in the Takamanda Gorilla Survey Project. WWF-US, Washington, DC, USA. 
Ferraro, P.J. \& Simpson, R.D. (2002) The cost-effectiveness of conservation payments. Land Economics, 78, 339-353.

GLCF (2010) Global Land Cover Facility. Http://glcf.umiacs.umd.edu/ index.shtml [accessed 9 May 2011].

GreEn, K. (1986) Assessing primate habitat using Landsat technology. In Primate Ecology and Conservation (eds J. Else \& P. Lee), Cambridge University Press, Cambridge, UK.

Gustafson, E.J. \& GARDnER, R.H. (1996) The effect of landscape heterogeneity on the probability of patch colonization. Ecology, 77, 94-107.

Hansen, M., DeFries, R., Townshend, J.R., Carroll, M., Dimiceli, C. \& Sohlberg, R. (2003) 50om MODIS Vegetation Continuous Fields version 1.o. The Global Land Cover Facility, College Park, USA.

Harcourt, A.H. (1996) Is the gorilla a threatened species? How should we judge? Biological Conservation, 75, 165-176.

Harcourt, A.H. \& Doherty, D.A. (2005) Species-area relationships of primates in tropical forest fragments: a global analysis. Journal of Applied Ecology, 42, 630-637.

Imong, I. (2005) 2005 Afi Mountain Census Report. Wildlife Conservation Society Biodiversity Research Programme, Calabar, Nigeria.

Imong, I. \& Dunn, A. (2005) A Gorilla Reconnaissance Survey of the Okwa Hills, Okwangwo Division, Cross River National Park. Wildlife Conservation Society Biodiversity Research Programme, Calabar, Nigeria.

Iremonger, S., Ravilious, C. \& Quinton, T. (1997) A Global Overview of Forest Conservation CD-ROM. World Conservation Monitoring Centre and Centre for International Forestry Research, Cambridge, UK.

ITE, U. \& ADAms, W. (2000) Expectations, impacts and attitudes: conservation and development in Cross River National Park, Nigeria. Journal of International Development, 12, 325-342.

IUCN (2010) IUCN Red List of Threatened Species v. 2010.4. Http:// www.iucnredlist.org [accessed 9 May 2011].

Johns, A. \& SKORUPA, J. (1987) Responses of rainforest primates to habitat disturbance: a review. International Journal of Primatology, 8, 157-191.

Kiss, A. (2004a) Is community-based ecotourism a good use of biodiversity conservation funds? Trends in Ecology \& Evolution, 19, 232-237

KIss, A. (2004b) Making biodiversity conservation a land-use priority. In Getting Biodiversity Projects to Work: Towards More Effective Conservation and Development (eds T.O. McShane \& M.P. Wells), pp. 98-123. Columbia University Press, New York, USA.

Kobler, A. \& ADAMIC, M. (2000) Identifying brown bear habitat by a combined GIS and machine learning method. Ecological Modelling, 135, 291-300.

Köndgen, S., Kühl, H., N'Goran, P.K., Walsh, P.D., Schenk, S., Ernst, N. et al. (2008) Pandemic human viruses cause decline of endangered great apes. Current Biology, 18, 260-264.

Kühl, H.F., Maisels, F., Ancrenaz, M. \& Williamson, E.A. (2008) Best Practice Guidelines for Surveys and Monitoring of Great Ape Populations. IUCN/Species Survival Commission Primate Specialist Group, Gland, Switzerland.

Kühl, H.F., Nzeingui, C., Le Duc Yeno, S., Huijbregts, B., Boesch, C. \& Walsh, P.D. (2009) Discriminating between village and commercial hunting of apes. Biological Conservation, $142,1500-1506$.

Laporte, N., Goetz, S., Justice, C. \& Heinicke, M. (1998) A new land cover map for central Africa derived from multi-resolution, multi-temporal AVHRR data. International Journal of Remote Sensing, 19, 3537-3550.
Larkin, J.L., Maehr, D.S., Hoctor, T.S., Orlando, M.A. \& Whitney, K. (2004) Landscape linkages and conservation planning for the black bear in west-central Florida. Animal Conservation, 7, 1-12.

Main, M.B., RokA, F.M. \& Noss, R.F. (1999) Evaluating costs of conservation. Conservation Biology, 13, 1262-1272.

Mansfield, A. (1908) Urwald Dokumente. Vier Jahre unter den Crossfluss-Negern Kameruns. Reimer, Berlin, Germany.

Martinez-Cruz, B., Godoy, A. \& Negro, J.J. (2004) Population genetics after fragmentation: the case of the endangered Spanish imperial eagle (Aquila adalberti). Molecular Ecology, 13, 22432255.

Mayeaux, P., Richards, T. \& Janodet, E. (1999) A vegetation map of central Africa derived from satellite imagery. Journal of Biogeography, 26, 353-366.

Мвон, H. \& W ARren, Y. (2007) Large Mammal Survey of the proposed Takamanda National Park. Unpublished Report to the Wildlife Conservation Society and KfW. Report 2 in the July 2007 series. Wildlife Conservation Society Takamanda-Mone Landscape Project, Limbe, Cameroon.

McDermid, G.J., Hall, R.J., Sanchez-Azofeifa, G.A., Franklin, S.E., Stenhouse, G.B., Kobliuk, T. \& LeDrew, E.F. (2009) Remote sensing and forest inventory for wildlife habitat assessment. Forest Ecology and Management, 257, 2262-2269.

McFARLAND, K.L. (2007) Ecology of Cross River Gorillas (Gorilla gorilla diehli) on Afi Mountain, Cross River State, Nigeria. PhD thesis, City University of New York Graduate Center, New York, USA.

MCGRAw, W.S. (2005) Update on the search for Miss Waldron's red colobus monkey (Procolobus badius waldroni). International Journal of Primatology, 26, 605-619.

McNeilage, A., Plumptre, A.J., Brock-Doyle, A. \& Vedder, A. (2001) Bwindi Impenetrable National Park, Uganda: gorilla census 1997. Oryx, 35, 39-47.

Miller, L., Savage, A. \& Giraldo, H. (2004) Quantifying remaining forested habitat within the historic distribution of the cotton-top tamarin (Saguinus oedipus) in Colombia: implications for long-term conservation. American Journal of Primatology, 64, 451-457.

Mittermeier, R.A., Wallis, J., Rylands, A.B., Ganzhorn, J., Oates, J.F., Williamson, E. et al. (eds) (2010) Primates in Peril: The World's 25 Most Endangered Primates 2008-2010. IUCN/Species Survival Commission Primate Specialist Group, Arlington, USA.

Naughton-Treves, N. \& Weber, W. (2001) Human dimensions of the African rainforest. In African Rain Forest Ecology and Conservation (eds W. Weber, L.J.T. White, A. Vedder \& N. Naughton-Treves), pp. 30-43. Yale University Press, New Haven, USA.

Nicholas, A. (2009) Gorilla guardians gain momentum. Gorilla Journal, 39, 12-14.

Noss, A.J. (1997) Challenges to nature conservation with community development in central African forests. Oryx, 31, 180-188.

Oates, J.F., Abedi-Lartey, M., McGraw, W.S., Struhsaker, T.T. \& Whitesides, G.H. (2000) Extinction of a West African red colobus monkey. Conservation Biology, 14, 1526-1532.

Oates, J.F., Bergl, R.A. \& Linder, J.M. (2004) Africa's Gulf of Guinea Forests: Biodiversity Patterns and Conservation Priorities. Conservation International Center for Applied Biodiversity Science, Washington, DC, USA.

Oates, J.F., Bergl, R.A., Sunderland-Groves, J. \& Dunn, A. (2008) Gorilla gorilla ssp. diehli. In IUCN Red List of Threatened Species v. 2010.4. Http://www.iucnredlist.org [accessed 9 May 2011].

Oates, J.F., McFarland, K.L., Groves, J.L., Bergl, R.A., Linder, J.M. \& Disotell, T.R. (2003) The Cross River gorilla: 
natural history and status of a neglected and critically endangered subspecies. In Gorilla Biology (eds A. Taylor \& M.L. Goldsmith), 472-497. Cambridge University Press, Cambridge, UK.

Oates, J.F., Sunderland-Groves, J., Bergl, R.A., Dunn, A., Nicholas, N., TAkang, E. et al. (2007) Regional Action Plan for the Conservation of the Cross River Gorilla (Gorilla gorilla diehli). IUCN Primate Specialist Group/Conservation International, Arlington, USA.

Pattanavibool, A. \& Dearden, P. (2002) Fragmentation and wildlife in montane evergreen forests, northern Thailand. Biological Conservation, 107, 155-164.

Pence, G.Q.K., Botha, M.A. \& Turpie, J.K. (2003) Evaluating combinations of on- and off-reserve conservation strategies for the Agulhas Plain, South Africa: a financial perspective. Biological Conservation, 112, 253-273.

Plumptre, A.J., McNeilage, A., Hall, J.S. \& Williamson, E. (2003) The current status of gorillas and threats to their existence at the beginning of a new millennium. In Gorilla Biology: A Multidisciplinary Perspective (eds A. Taylor \& M. Goldsmith), pp. 414-431. Cambridge University Press, Cambridge, UK.

Plumptre, A.J. \& Reynolds, V. (1994) The effect of selective logging on the primate populations in the Budongo Forest Reserve. Journal of Applied Ecology, 31, 631-641.

Pollini, J. (2009) Carbon sequestration for linking conservation and rural development in Madagascar: the case of the VohidrazanaMantadia Corridor Restoration and Conservation Carbon Project. Journal of Sustainable Forestry, 28, 322-342.

Rood, E. \& Ganie, A.A. (2010) Using presence-only modelling to predict Asian elephant habitat use in a tropical forest landscape: implications for conservation. Diversity and Distributions, 16, 975-984.

Rouget, M., Cowling, R.M., Lombard, A.T., Knight, A.T. \& Kerley, G.I.H. (2006) Designing large-scale conservation corridors for pattern and process. Conservation Biology, 20, 549-561.

Russon, A., Erman, A. \& Dennis, R. (2001) The population density of orang-utans (Pongo pygmaeus pygmaeus) in and around the Denau Sentarum Wildlife Reserve, West Kalimantan, Indonesia. Biological Conservation, 97, 21-28.

Schadt, S., Knauer, F., Kaczensky, P., Revilla, E., Wiegand, T. \& Trepl, L. (2002) Rule-based assessment of suitable habitat and patch connectivity for the Eurasian lynx. Ecological Applications, 12, 1469-1483.

Schiøтz, A. (1999) Treefrogs of Africa. Edition Chimaira, Frankfurt am Main, Germany.

Slayback, D. (2003) Land cover change in the Takamanda Forest Reserve, Cameroon: 1986-2000. In Takamanda: The Biodiversity of an African Rainforest. (eds J.A. Comiskey, T. Sunderland \& J.L. Sunderland-Groves), pp. 173-179. Smithsonian Institution, Washington, DC, USA.

Sunderland, T.C.H., Comiskey, J.A., Besong, S., Мвон, H., Fonwebon, J. \& Dione, M.A. (2003) Vegetation survey of Takamanda Forest Reserve, Cameroon. In Takamanda: The Biodiversity of An African Rainforest (eds J.A. Comiskey, T.C.H. Sunderland \& J.L. Sunderland-Groves), pp. 19-53. Smithsonian Institution, Washington, DC, USA.

Sunderland-Groves, J.L., Ekinde, A. \& Мвон, H. (2009) Cross River gorilla (Gorilla gorilla diehli) nesting behaviour at Kagwene Mountain, Cameroon: implications for assessing group size, age- structure and density at other Cross River gorilla localities. International Journal of Primatology, 30, 253-266.

Sunderland-Groves, J.L., Maisels, F. \& Ekinde, A. (2003) Surveys of the Cross River gorilla and chimpanzee populations in Takamanda Forest Reserve, Cameroon. In Takamanda: The Biodiversity of an African Rainforest (eds J.A. Comiskey, T.C.H. Sunderland \& J.L. Sunderland-Groves), pp. 129-140. Smithsonian Institution, Washington, DC, USA.

Thalmann, O., Wegmann, D., Spitzner, M., Arandjelovic, M., Guschanski, K., Leuenberger, C. et al. (2011) Historical sampling reveals dramatic demographic changes in western gorilla populations. BMC Evolutionary Biology, 11, 85.

Thomas, L., Laake, J.L., Strindberg, S., Marques, F.F.C., Buckland, S.T., Borchers, D.L. et al. (2006) Distance 5.0 Release 2. Research Unit for Wildlife Population Assessment. University of St Andrews, St Andrews, UK.

USGS (2004) Shuttle Radar Topography Mission. Global Land Cover Facility. University of Maryland, College Park, USA.

van Schaik, C., Monk, K. \& Yarrow Robertson, J. (2001) Dramatic decline in orang-utan numbers in the Leuser ecosystem, Northern Sumatra. Oryx, 35, 14-25.

Wikramanayake, E., McKnight, M., Dinerstein, E., Joshi, A., Gurung, B. \& Smith, D. (2004) Designing a conservation landscape for tigers in human-dominated environments. Conservation Biology, 18, 839-844.

Wilkie, D.S. \& LAPORTE, N. (2001) Forest area and deforestation in Central Africa: current knowledge and future directions. In African Rainforest Ecology and Conservation (eds W. Weber, L. White, A. Vedder \& L. Naughton-Treves), pp. 119-139. Yale University Press, New Haven, USA.

Wunder, S., Engel, S. \& Pagiola, S. (2008) Taking stock: a comparative analysis of payments for environmental services programs in developed and developing countries. Ecological Economics, 65, 843-852.

\section{Biographical sketches}

RICHARD BERGL has been conducting conservation-relevant research on the Cross River gorilla since 1999. He currently directs the North Carolina Zoo's Conservation and Research Programme. YMKE WARREN studied primate ecology and behaviour at a number of sites across Africa. She led Cross River gorilla research and monitoring work in Cameroon until her untimely death in 2010. Aaron Nicholas directed the Wildlife Conservation Society's Takamanda-Mone Landscape Programme between 2006 and 2010. AndRew Dunn is the Country Director of the Wildlife Conservation Society, Nigeria and has conducted wildlife research and managed conservation projects in West Africa for over 20 years. INAOYOM IMONG has conducted research on the Cross River gorilla since 2004. $\mathrm{He}$ is currently carrying out research on the influence of food availability on the distribution of the Cross River gorilla. JACQUELINE Sunderland-Groves established and directed Cross River gorilla research and conservation activities in Cameroon from 1997 to 2006. John F. OAtes has been studying the behaviour, ecology and evolution of primates, especially in West Africa, since 1964. 